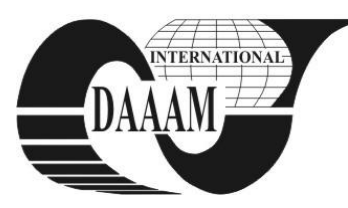

Annals of DAAAM for 2011 \& Proceedings of the 22nd International DAAAM Symposium, Volume 22, No. 1, ISSN 1726-9679 ISBN 978-3-901509-83-4, Editor B. Katalinic, Published by DAAAM International, Vienna, Austria, EU, 2011 Make Harmony between Technology and Nature, and Your Mind will Fly Free as a Bird Annals \& Proceedings of DAAAM International 2011

\title{
THE LINEARISED CONTROL SYSTEM OF THE PNEUMATIC ACTUATOR
}

\author{
BALARA, M[ilan]
}

\begin{abstract}
The article contains information about the function and basic properties of the actuator based on pneumatic artificial muscles. It describes the design of control structure of such actuator and shows the configuration of the non-linear actuator together with non-linear (compensation) control unit. The resulting position servosystem with linearized overall static characteristics has favorable results. They are presented by experimentaly measured step responses.
\end{abstract}

Key words: actuator, artificial muscle, static characteristic, compensation, non-linearity

\section{INTRODUCTION}

Pneumatic position servosystems for various devices sometimes use pneumatic artificial muscles as actuator. They usually form a system with so called antagonistic configuration, which presents driving part of the system - servosystem actuator. Artificial muscles (AM) act against each other by their pulling forces and resulting position is determined by the balance of the pulling forces at different air pressure in each AM (Novák-Marcinčin, 1993).

Pulling forces of the AM are transferred by string (or chain) to the roller. The stiffness of such device depends on the forces produced by each AM. This configuration is being used often and it has many advantages (Fig. 1). It is necessary to use two electropneumatic valves to control each AM. Each AM requires one supply and one bleed valve, either of proportional or two position types. The valves of both AMs are controlled simultaneously, which puts high demands on control algorithm of the controller (Pitel' \& Boržíková, 2009).

\section{STATIC CHARACTERISTICS OF THE ANTAGONISTIC ACTUATOR}

The actuator (Fig. 1) together with the load forms a controlled system, the output of which is position (alternatively velocity or acceleration), i.e. the angle $\beta$ of the arm $r$. The input to the actuator is air pressure $p$, which is supplied to the appropriate AM. Because the system is formed by the couple of the AMs, the arm angle depends on the pressure difference between each AM. The dependence of the arm angle $\beta$ on the pressure difference $p_{s v d}$ of the AMs was measured experimentally and represents static characteristics of the system. It is a non-linear function and is symmetric around the origin of the coordinate system.

In general, the function of arm angle dependent on supplied air pressure for any type of the AM is as follows:

$$
\beta\left(p_{s v d}\right)=\left(a_{0}-a_{1} e^{-\left|p_{s v d}\right|}+a_{2}\left|p_{s v d}\right| \cdot e^{-\left|p_{s v d}\right|}\right) \cdot \operatorname{sign}\left(p_{s v d}\right)
$$

The formula of the given real system with a couple of AMs is as follows (Balara, 2011):

$$
\beta\left(p_{s v d}\right)=\left(35,135-34,444 e^{-\left|p_{s v d}\right|}+5,47 q\left|p_{s v d}\right| \cdot e^{-\left|p_{s v d}\right|}\right) \cdot \operatorname{sign}\left(p_{s v d}\right)
$$

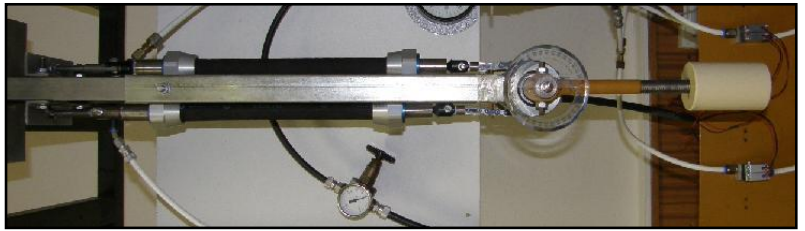

Fig. 1. The actuator with pneumatic artificial muscles in antagonistic configuration. Artificial muscles have equal supply pressures and the resulting arm position is in initial (reference) point. Artificial muscles used here are Festo MAS 20 - 250.

The graph of this function is shown in the Fig. 2 and represents non-linear static characteristics of the actuator with artificial muscles Festo MAS $20-250$.

\section{THE DESIGN OF CONTROL AND COMPENSATION OF ACTUATOR NON- LINEARITY}

Suggested actuator position control is simpler comparing to regular control described earlier. One of the AMs in the respective half of the arm path serves as passive non-linear pneumatic spring and does not require any control actions (in commonly used systems both valves have to be controlled simultaneously). Only active AM is being controlled and the position is being set by setting the air pressure through the respective valve.

In the second half of the arm path the operation of the actuator is the same except the function of the AMs exchange. This solution simplifies the control of such system, provides higher stiffness and continuous movement of the arm.

According to assumptions as well as from the Fig. 2 it is obvious that the static characteristics of the actuator is nonlinear. It is a continouous function and represents non-linearity of saturation type. Control of such non-linear element brings remarkable problems with preservation of its static and dynamic properties at various values of the control input as well as at various load torque.

That is why it is suitable to include compensation element, designed by author. This solution would completely or partially linearise the system containing non-linear regulator and nonlinear system (actuator with load). In case of pneumatic actuator in antagonistic configuration, which is a non-linear and single-dimensional system, it can be stated that regulator of such system would also be non-linear and single-dimensional. Its non-linear characteristics would be complementary function of the static characteristics of the controlled object with appropriate consideration of gains of elements placed between respective non-linearities.

The gain of compensation block must be a non-linear function, which is reciprocal value of the system gain.

Experimental measurements showed that in spite of relatively good linearization, the regulator provides too low gain for static gain around zero, which was causing permanent regulation deviation. The transfer function of the compensation 
element needed to be modified so that it would provide higher gain around zero (by adding extra non-linearity).

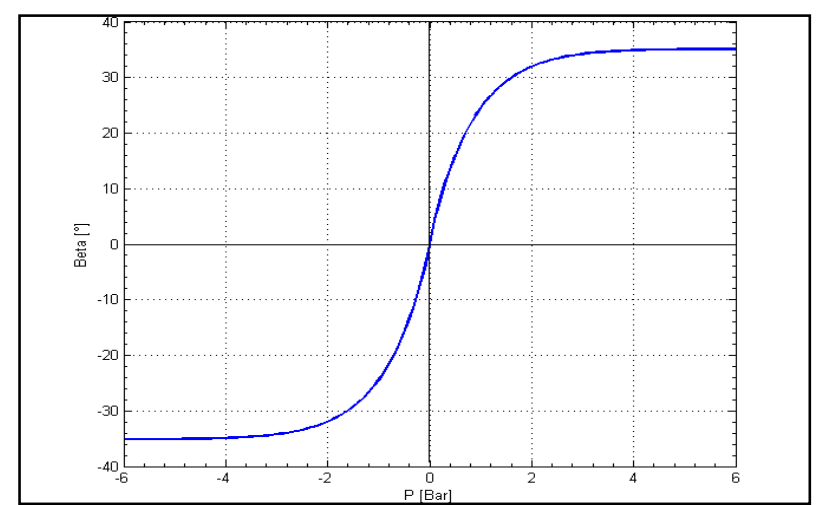

Fig. 2. Static characteristics of the antagonistic actuator with artificial muscles Festo MAS 20 - 250 expressed by exponential function (2)

Original function of compensation element was hence modified as follows:

$$
y=2\left[\left(1-e^{-a b s\left(\frac{x}{a}\right)}+0,8 * 1,4391 \cdot \tan \left(\frac{a b s(x)}{7}\right)\right)\right] \operatorname{sign}(x)
$$

after further modification we get

$$
y=2\left[\left(1-e^{-a b s\left(\frac{x}{a}\right)}+1,14553 \cdot \tan \left(\frac{a b s(x)}{7}\right)\right)\right] \operatorname{sign}(x)
$$

Where $a$ is a curve tangent line slant coefficient at the origin of the coordinate system and its optimal value 0,9 was determined experimentally on the subjected system. The going of that function is shown in the Fig. 3, where $U_{r}$ represents block input and $U_{r k}$ represents block output.

The compensation block according to Fig. 3 and algorithm (4) was added to the output of the PI regulator of the antagonistic actuator with artificial muscles Festo MAS $20-$ 250 (Fig. 1). The load of weight $2,14 \mathrm{~kg}$ was put on the arm of length $0,23 \mathrm{~m}$, which represents the load of the servosystem. The regulator without compensation was optimized by ZieglerNichols method at lower load $(1,2 \mathrm{~kg})$. The system's load was then varied with the optimized regulator parameters and transient responses were recorded.

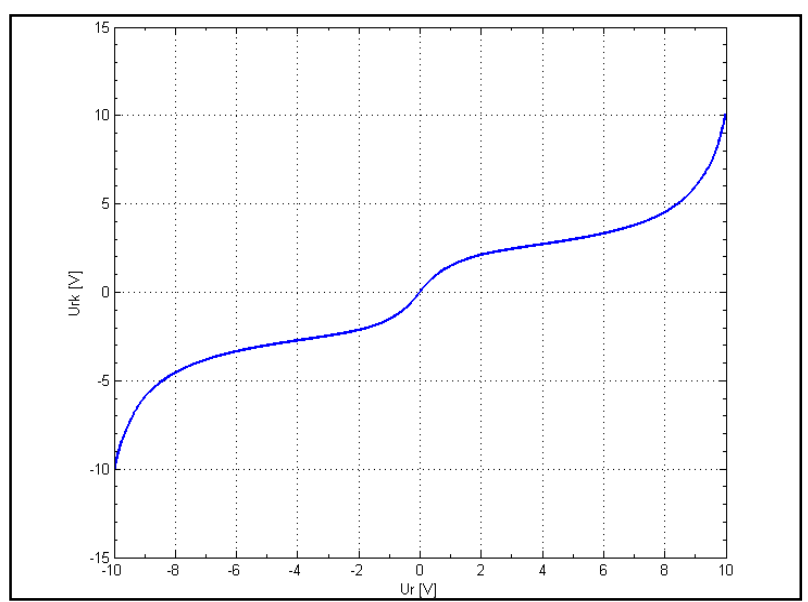

Fig. 3. Static characteristics of the compensation block connected to the output of the PI regulator ( $U_{r}-$ block input, $U_{r k}$-block output)

Transient responses of the system with variable load and higher were having oscillations in steady state. Adding the compensation block changed the situation dramatically, the system got stable and has smooth transient responses for the whole range of load, i.e. from no load to maximal load ( $m=$ $2,14 \mathrm{~kg}$ ).

Transient responses of the real system are shown in the Fig. 4. It is obvious that non-linearity compensation increases precision of regulation and stabilizes the system.

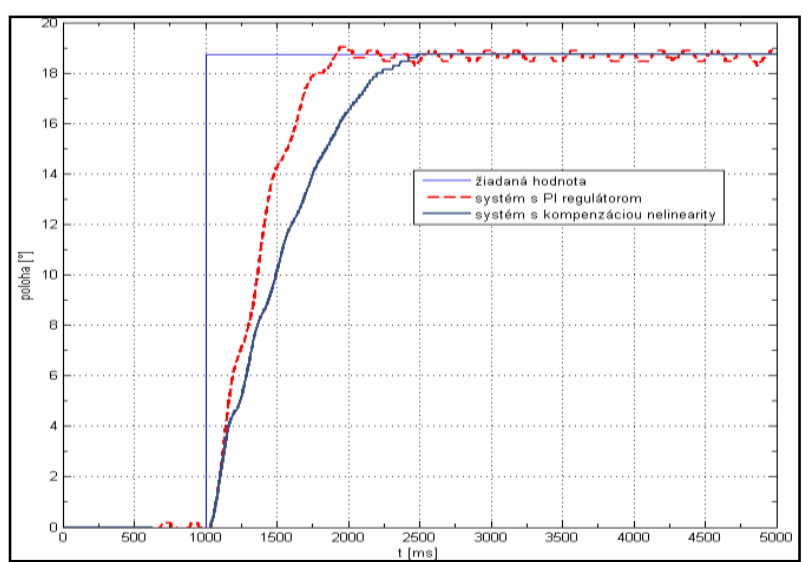

Fig. 4. Transient reponses of the position servosystem with PI regulator. Desired value - blue, response of the plain PI regulator - dotted red, response of the PI regulator with nonlinear compensation - dark blue

\section{CONCLUSION}

The position control system formed by the non-linear pneumatic actuator together with relatively simple non-linear compensation linearizes overall static characteristics of the system. That dramatically enhances the quality of control. Transient responses of the real functional system obviously prove that compensation of system non-linearity stabilizes the system and improves precision of regulation.

\section{ACKNOWLEDGEMENTS}

The research work is supported by the Project of the Structural Funds of the EU „Research and development of intelligent nonconventional actuators based on artificial muscles”, ITMS code: 26220220103.

\section{REFERENCES}

Balara, A. (2011). Príspevok ku zdokonal'ovaniu metód počítačovej podpory pohybu aktuátorov technologických zariadení. Dizertačná práca, Prešov, TU v Košiciach, FVT so sídlom v Prešove

Boržíková, J. \& Pitel', J. (2008). Nonlinearity of Static Characteristics of the Antagonistic System, Proceedings of XXI International Scientific Conference „, Mathematical Methods in Technics and Technologies MMTT-21 ", May 27-30, 2008, Saratov, ISBN 978-5-7433-1933-6, pp. $196-197$, SGTU, Saratov

Hošovský, A. (2008). Riadenie polohového servosystému na báze pneumatických umelých svalov s aplikáciou akceleračnej slučky. Dizertačná práca, Prešov, TU v Košiciach, FVT so sídlom v Prešove

***Novák - Marcinčin, J. (1993). Biomechanizmy, Elfa, ISBN 80-7099-218-2, Košice

***Pitel', J. \& Boržíková, J. (2009). Model of the Pneumatic Actuator Based on Artificial Muscles, Proceedings of XXII International Scientific Conference „Mathematical Methods in Technics and Technologies MMTT-22 ", May 25-28, 2009, Pskov, ISBN 978-5-91116-087-2, pp. $102-$ 104, PGPI, Pskov 